\title{
Locking of helicity and shape complementarity in diarylethene dimers on graphite
}

\author{
Nathalie Katsonis*, Andrea Minoia, Tibor Kudernac, Toshiki Mutai, Hong Xu, Hiroshi Uji-i, \\ Roberto Lazzaroni* ${ }^{\star}$ Steven De Feyter ${ }^{\star}$, Ben L. Feringa* \\ Department of Organic and Molecular Inorganic Chemistry, Stratingh Institute, University of \\ Groningen, Nijenborgh 4, 9747 AG Groningen, the Netherlands, Department of Chemistry, Laboratory \\ of Photochemistry and Spectroscopy and INPAC-Institute for Nanoscale Physics and Chemistry, \\ Katholieke Universiteit Leuven, Celestijnenlaan 200-F, B-3001 Leuven, Belgium, and Laboratory for \\ Chemistry of Novel Materials, University of Mons-Hainaut, Materianova, B-7000 Mons, Belgium. \\ B.L.Feringa @ rug.nl, Steven.Defeyter@chem.kuleuven.be, Roberto@averell.umh.ac.be, N.H.Katsonis@ rug.nl
}

\section{Supporting Information}

\section{Materials}

Reagents and starting materials were used as obtained from Aldrich and Acros Chimica, Fluka or Merck. ${ }^{1} \mathrm{H}$ NMR spectra were recorded on a Varian VXR-300 spectrometer (at $300 \mathrm{MHz}$ ) at ambient temperature. ${ }^{13} \mathrm{C}$ NMR spectra were recorded on a Varian VXR300 (at $75.4 \mathrm{MHz}$ ). Chemical shifts are denoted in $\delta(\mathrm{ppm})$ referenced to the residual $\mathrm{CHCl}_{3}$ peaks. Coupling constants $J$, are denoted in $\mathrm{Hz}$. The splitting patterns are designated as following: s (singlet), $\mathrm{d}$ (doublet), $\mathrm{t}$ (triplet), q (quartet), $\mathrm{m}$ (multiplet). Mass spectra were recorded with a Joel JMS-600 mass spectrometer by Mr. A. Kiewiet with ionisation according to CI, DEI, EI procedures. Aldrich, silica gel, Merck grade 9385, (230-400 mesh) was used for column chromatography. If necessary, solvents were distilled and dried before use by standard methods.

\section{Synthesis}

Compound 5 was synthesized according to the Scheme 1. 2-Bromo-5-octadecylthiophene 3 was prepared by bromination of previously described 2-octadecylthiophene $\mathbf{2}^{1}$. The last step involved treatment of known compound $4^{2}$ with $\mathrm{t}-\mathrm{BuLi}$ and tributylborate and subsequent palladium catalyzed coupling with $\mathbf{3}$ giving $\mathbf{5}$ in $21 \%$ yield. 

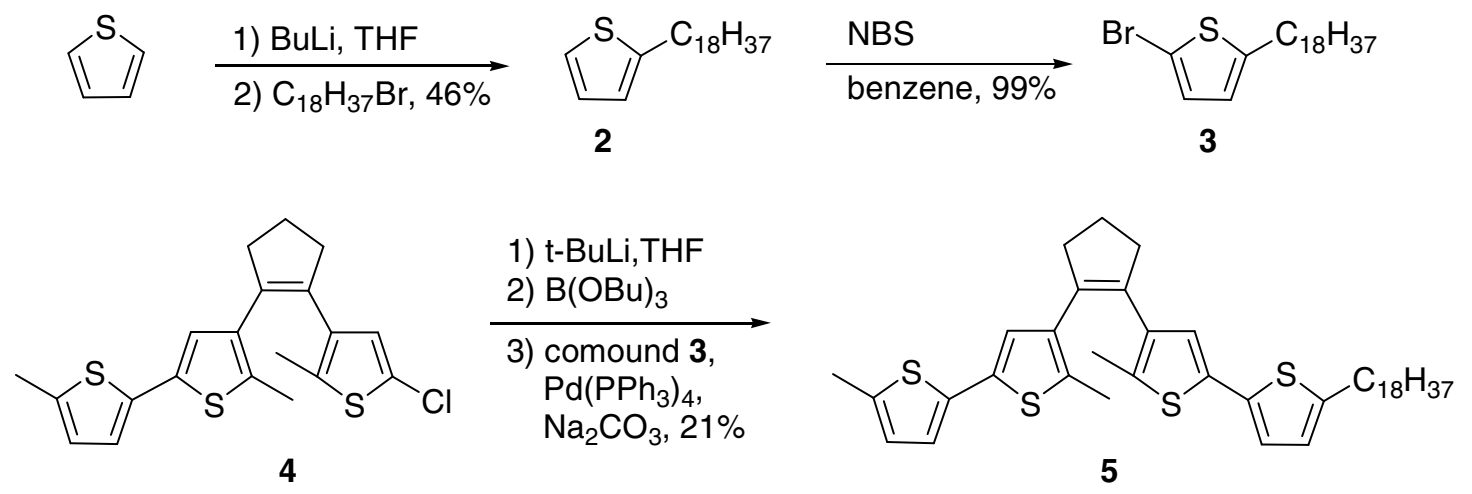

Scheme 1.

\section{2-Octadecylthiophene (2)}

To a solution of thiophene $(4 \mathrm{ml}, 48 \mathrm{mmol})$ in THF $(20 \mathrm{ml})$ was dropwise added $n$ butyllithium $\left(15 \mathrm{ml}, 1.6 \mathrm{M}\right.$ of hexane solution) at $0^{\circ} \mathrm{C}$, and stirred for $1 \mathrm{~h}$ at room temperature. Bromooctane $(8.0 \mathrm{~g}, 48 \mathrm{mmol})$ in $\mathrm{THF}(10 \mathrm{ml})$ was slowly added at $0^{\circ} \mathrm{C}$, then the reaction was maintained at $50{ }^{\circ} \mathrm{C}$ for $6 \mathrm{~h}$. After the reaction was quenched with water, the organic layer was washed with water and brine, and dried over magnesium sulfate. Evaporation of the solvent gave the yellow oil, which was then applied to a silica gel column and eluted with petroleum ether $\left(40-60{ }^{\circ} \mathrm{C}\right)$. Previously described compound $\mathbf{2}^{1}$ was obtained as slightly yellow oil $(7.8 \mathrm{~g}, 46 \%) .{ }^{1} \mathrm{H}$ NMR $\left(\mathrm{CDCl}_{3}, 300 \mathrm{MHz}\right) \delta_{\mathrm{H}} 7.07$ $(\mathrm{d}, J=5.1 \mathrm{~Hz}, 1 \mathrm{H}), 6.88(\mathrm{t}, J=4.2 \mathrm{~Hz}, 1 \mathrm{H}), 6.74-6.75(\mathrm{~m}, 1 \mathrm{H}), 2.79(\mathrm{t}, J=7.6 \mathrm{~Hz}, 2 \mathrm{H})$, $1.60-1.68(\mathrm{~m}, 2 \mathrm{H}), 1.08-1.29(\mathrm{~m}, 30 \mathrm{H}), 0.87(\mathrm{t}, J=6.6 \mathrm{~Hz}, 3 \mathrm{H}) \mathrm{ppm}$.

\section{2-Bromo-5-octadecylthiophene (3)}

To a vigorously stirred solution of 2-octadecylthiophene $(7.8 \mathrm{~g}, 23.2 \mathrm{mmol})$ and $\mathrm{N}$ bromosuccinimide $(5.1 \mathrm{~g}, 28.7 \mathrm{mmol})$ in benzene $(80 \mathrm{ml})$ two droplets of bromine were added. The reaction mixture was stirred for $1,5 \mathrm{~h}$. The organic layer was washed with water and brine, and then dried over magnesium sulfate. Evaporation of the solvent gave the product 3 quantitatively $\left(9.4\right.$ g). m.p. $41-42{ }^{\circ} \mathrm{C} ;{ }^{1} \mathrm{H}$ NMR $\left(300 \mathrm{MHz}, \mathrm{CDCl}_{3}\right): \delta_{\mathrm{H}} 0.88$ (t, $J=6.6 \mathrm{~Hz}, 3 \mathrm{H}), 1.25(\mathrm{br}, 30 \mathrm{H}), 1.62(\mathrm{t}, \mathrm{J}=6.9 \mathrm{~Hz}, 2 \mathrm{H}), 2.73(\mathrm{t}, J=7.7 \mathrm{~Hz}, 2 \mathrm{H}), 6.52-$ $6.53(\mathrm{~m}, 1 \mathrm{H}), 6.83-6.85(\mathrm{~m}, 1 \mathrm{H}) \mathrm{ppm} ;{ }^{13} \mathrm{C}$ NMR $\left(75.4 \mathrm{MHz}, \mathrm{CDCl}_{3}\right): \delta_{\mathrm{C}} 14.1(\mathrm{q}), 22.7(\mathrm{t})$, $29.0(\mathrm{t}), 29.3(\mathrm{t}), 29.4(\mathrm{t}), 29.4(\mathrm{t}), 29.5(\mathrm{t}), 29.6(\mathrm{t}), 29.7(\mathrm{t}), 29.7(\mathrm{t}), 30.3(\mathrm{t}), 31.4(\mathrm{t})$, $31.9(\mathrm{t}), 108.5$ (s), 124.3 (d), 129.3 (d), 147.6 (s) ppm; HRMS: calcd. for $\mathrm{C}_{22} \mathrm{H}_{39} \mathrm{SBr}$ 416.195, found 416.194 .

\section{1-[5'-(5"-Methylthien-2"'-yl)-2'-methylthien-3'-yl]-2-[5'-(5"'-octadecylthien-2'-yl)- 2'-methylthien-3'-yl)cyclopentene (5)}

To a solution of compound $4(0.83 \mathrm{~g}, 2.12 \mathrm{mmol})$ in THF $(20 \mathrm{ml})$, kept under an inert $\mathrm{N}_{2}$ atmosphere, t-BuLi (1.4 $\mathrm{ml}$ of $1.5 \mathrm{M}$ solution in pentane) was added. After $1 \mathrm{~h}, \mathrm{~B}(\mathrm{OBu})_{3}$ $(0.57 \mathrm{ml}, 2.12 \mathrm{mmol})$ was added and the mixture was stirred for $1 \mathrm{~h}$ to produce a boronic ester intermediate. In a separate flask bromide $3(1.15 \mathrm{~g}, 2.77 \mathrm{mmol}), \mathrm{Pd}\left(\mathrm{PPh}_{3}\right)_{4}(0.05 \mathrm{~g})$, THF (10 ml), (aq.) $2 \mathrm{M} \mathrm{Na}_{2} \mathrm{CO}_{3}(10 \mathrm{ml})$ and ethylene glycol (10 drops) were preheated to $80{ }^{\circ} \mathrm{C}$ and the formed boronic ester was added slowly. The reaction mixture was heated under reflux overnight, diluted with diethyl ether $(100 \mathrm{ml})$ and washed with water (100 $\mathrm{ml})$. The water layer was washed with an additional volume of ether $(100 \mathrm{ml})$ and the 
combined organic phases were dried over $\mathrm{Na}_{2} \mathrm{SO}_{4}$ and concentrated. Subsequent chromatography on silica gel (petroleum ether 40-60) afforded compound $\mathbf{5}$ as a pale green solid (0.31 g, $21 \%$ ). m.p. $60-61{ }^{\circ} \mathrm{C} ;{ }^{1} \mathrm{H} \mathrm{NMR}\left(\mathrm{CDCl}_{3}, 300 \mathrm{MHz}\right) \delta_{\mathrm{H}} 0.88(\mathrm{t}, 3 \mathrm{H})$, $1.26(\mathrm{br}, 30 \mathrm{H}), 1.65(\mathrm{t}, 2 \mathrm{H}), 1.91(\mathrm{~s}, 3 \mathrm{H}), 1.92(\mathrm{~s}, 3 \mathrm{H}), 2.01-2.06(\mathrm{~m}, 2 \mathrm{H}), 2.43(\mathrm{~s}, 3 \mathrm{H})$, 2.72-2.81 (m, 6H), 6.59-6.61 (m, 2H), 6.80-6.84 (m, 4H) ppm; ${ }^{13} \mathrm{C}$ NMR $(75.4 \mathrm{MHz}$, $\left.\mathrm{CDCl}_{3}\right): \delta_{\mathrm{C}} 14.1(\mathrm{q}), 14.3(\mathrm{q}), 15.3(\mathrm{q}), 22.7(\mathrm{t}), 22.9(\mathrm{t}), 29.1(\mathrm{t}), 29.4(\mathrm{t}), 23.5(\mathrm{t}), 29.6$ $(\mathrm{q}), 29.7(\mathrm{t}), 30.1(\mathrm{t}), 31.6(\mathrm{t}), 31.9(\mathrm{t}), 38.5(\mathrm{t}), 122.5(\mathrm{~d}), 122.7(\mathrm{~d}), 123.7(\mathrm{~d}), 123.8(\mathrm{~d})$, 124.5 (d), 125.7 (d), 133.3 (s), 133.4 (s), 133.4 (s), 133.5 (s), 134.4 (s), 134.5 (s), 135.1 (s), 135.5 (s), 136.1 (s), 136.2 (s), 138.4 (s), 144.7 (s) ppm; HRMS: calcd. for $\mathrm{C}_{42} \mathrm{H}_{58} \mathrm{~S}_{4}$ 690.340, found 690.342. Anal. calcd for $\mathrm{C}_{42} \mathrm{H}_{58} \mathrm{~S}_{4}$ : C 72.98, H 8.46; found: $\mathrm{C} 72.68, \mathrm{H}$ $8.27 \%$.

\section{Scanning Tunneling Microscopy}

All experiments were performed at room temperature. Pt/Ir STM tips were prepared by mechanical cutting from Pt/Ir wire $(80: 20$, diameter $0.25 \mathrm{~mm})$. The preparation of the sample was done carefully in the dark to prevent photoisomerisation. Prior to imaging, the diarylethene derivative was dissolved in1-phenyloctane (Aldrich) by sonication (few min). After $1 \mathrm{~h}$ heating at $40^{\circ} \mathrm{C}$, a drop of the solution was applied to a freshly cleaved surface of graphite (Goodfellow), and then the STM tip was immersed into the drop. STM imaging was performed at the solution-HOPG interface on a MI Picoscan. The presented images are subjected to a first-order plane-fitting procedure to compensate for sample tilt.

\section{Schemes}

Schematic representation of anti-parallel and parallel conformations of diarylethene $\mathbf{1}$.

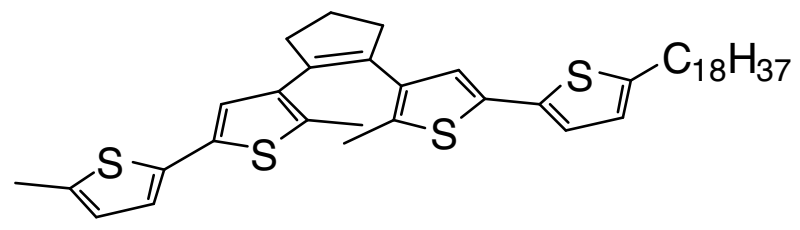

anti-parallel

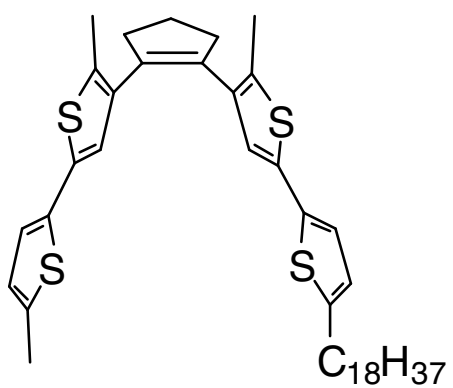

parallel

\section{References}

1 (a) Wynberg, H.; Logothetis, A. J. Am. Chem. Soc. 1956, 78, 1958. (b) Miller, K. E.; Haymaker, C.; Gilman, H. J. Org. Chem. 1959, 24, 622.

2 Kudernac, T.; van der Molen, S. J.; van Wees, B. J.; Feringa, B. L. Chem. Commun. 2006, 3597. 